\title{
Un embarazo complicado con parálisis de origen medular
}

\author{
Doctor Jesús Alberto Gómez Palacino \\ Asistente de Cátedra de Clínica Obstétrica
}

N. N., de veinticinco años. Ingresa al Instituto Maternoinfantil el 2 de mayo de 1957. Tercigestante con dos partos espontáneos a término sin complicaciones e hijos sanos. Ignora la fecha de la última menstruación.

El embarazo transcurrió sin mayores molestias hasta hace cuatro días, cuando experimentó un dolor súbito en la región dorsal y cuatro horas después presentaba una parálisis completa de miembros inferiores con paresia de los superiores y pérdida completa de la sensibilidad de la región mamaria hacia abajo.

La paciente se queja de cefalea, calofrío y fiebre. Hay retención de orina y de materias fecales.

El examen general revela un estado general aceptable con las siguientes particularidades: pulso de 74 por minuto con arritmia extrasistólica, T. A. de $80 \times 40$, temperatura de 37 gracios centígrados.

Desde el punto de vista neurológico se encuentra: paraplejía flácida en miembros inferiores y paresia de miembros superiores. Marcada hipotonía generalizada con abolición de los reflejos rotulianos, plantares y aquilianos. En miembros superiores hay hiporreflexia simétrica con disminución de la fuerza muscular para los movimientos de flexión y extensión de los dedos. Todas las formas de sensibilidad se encuentran abolidas a partir de un nivel correspondiente a la dermatoma torácica D2 con zona hiperestésica en D1. Hay dolor a la palpación y percusión de las apófisis espinosas de C7 hasta D2 y dolor en los movimientos de rotación de la cabeza con moderada rigidez 
de la nuca. Hay abolición de la sensibilidad en la zona de distribución correspondiente a las dermatomas C8 a D1 en la cara interna de miembros superiores. Pares craneanos normales, fonco de ojo normal.

Desde el punto de vista digestivo y urinario y en relación probable con el cuadro descrito, se encuentra retención de orina $y$ de materias fecales.

El examen obstétrico muestra un embarazo correspondiente aproximadamente a ocho meses de evolución con feto vivo en OD alta. El T. V. no demuestra iniciación de trabajo del parto. Ia palpación del útero despierta contracciones que la paciente no aprecia.

Examinada por los neurólogos se hacen los siguientes diagnósticos de presunción: 1) Mielitis transversa aguda; 2) Absceso epidural; 3) Trombosis de las arterias espinales anteriores. Se ordenan los exámenes.

Laboratorio: 1) L. C. R. Se practica punción entre L4 y L5 con aguja número 20; presión inicial 14 centímetros, por comprensión abdominal sube a 22 y con compresión yugular sube inicialmente con dificultad y luego rápidamente hasta 41. Presión final: 6. Se extraen 8 C. C. de L. C. R. incoloro, transparente y que al análisis da: Ross Jones (-), Pandy (-), células por mm3 13, cloruros 720 miligramos\%, proteínas 11 miligramos\%, cardiolipina (-), glucosa 32 miligramos\%, curva de benjuí, 0000003100000000 .

2) Cuadro hemático: Hematíes, 3.680 .000 ; leucocitos, 8.000 por mm.3; hemoglobina, 11.8 gramos\%; hematocrito, $35 \%$; neutrófilos, $60 \%$; eosinófilos, $1 \%$; linfocitos pequeños, $38 \%$; sedimentación, $6 \mathrm{~mm}$ a la media hora y $12 \mathrm{~mm}$. a la hora.

3) Serologia: (-).

4) Azoemia: 62,5 miligramos\%. Glicemia: 95 miligramos\%.

5) T. de coagulación (Lee-White) : 6 minutos. T. de protrombina (Howel): 5 minutos.

6) Orina: Acida, con huellas de albúmina y de glucosa. Sedimento: hematíes, piocitos, uratos amorfos, bacterias y células epiteliales.

7) Electrocardiograma: "El trazo indica bradicardia sinusal" (43 x min.). 
8) Radiografia de columna cérvico-dorsal: negativa.

CONDUCTA: El examen clínico del día siguiente al de su ingreso, demostró los mismos hallazgos iniciales con gran bradicardia, arritmia cardíaco y dificultad respiratoria. En estas condiciones resolvimos practicar una intervención cesárea teniendo en cuenta la gravedad del cuadro clínico con la posibilidad fatal para madre e hijo.

La operación se realizó sin contratiempos y se obtuvo un feto vivo de 2.500 gramos. No se administró ninguna medicación anestésica durante la intervención, desde luego que la lesión medular ocasionó los mismos efectos de una anestesia raquídea.

Desde el punto de vista obstétrico no hubo complicaciones post-operatorias: la involución uterina y la cicatrización de las suturas fueron perfectas.

EVOLUCION: Los exámenes siguientes y la evolución misma del caso, demostraron que se trataba de una posible hematomieiia que hizo necesaria la práctica de una traqueotomía de urgencia. Días más tarde la paciente falleció.

COMENTARIO: Presentamos un caso clínico excepcional en el cual hubimos de adoptar una conducta quirúrgica en vista de la gravedad del cuadro clínico y ante el riesgo de llegar tarde a una decisión obstétrica. Los resultados nos concedieron la razón, pues se obtuvo un feto en buenas condiciones, mientras que el estado de la madre se fue agravando hasta llegar al deceso.

N. R.: Es lástima que el caso no fuera confirmado por autopsia. 